\title{
Pembelajaran Daring dengan Intervensi Video Pembelajaran Pada Masa Pandemi Covid 19
}

\author{
Sulistiani1), Suminto2), Ari Suningsih ${ }^{3)}$ \\ 1), 2),3) Universitas Muhammadiyah Pringsewu \\ email: suminto@umpri.ac.id
}

\begin{abstract}
Abstrak
Pandemi Covid-19 di Indonesia membuat sistem pembelajaran berubah menjadi pembelajaran daring, sehingga kreatifitas guru mengembangkan media dan metode pembelajaran daring menjadi penting. Tujuan penelitian ini adalah untuk mengetahui perbedaan rata-rata hasil belajar siswa antara pembelajaran daring menggunakan media group WhatsApp dengan media group WhatsApp yang diberikan intervensi video pembelajaran. Populasi dari penelitian ini adalah siswa kelas VIII (8C, 8D, 8E, dan 8F) SMP N 1 Air Naningan, dengan teknik purposive sampling sehingga terpilih 30 siswa sebagai sampel penelitian. Instrumen penelitian yang digunakan adalah tes soal materi persamaan garis lurus yang berjumlah 5 soal. Data sampel diolah dengan uji t-berpasangan (Paired Samples Test) yang dilakukan pada kedua kelompok. Hasil penelitian menyimpulkan bahwa terdapat perbedaan rata-rata hasil belajar siswa yang menggunakan media group WhatsApp dengan rata-rata hasil belajar siswa menggunakan media group WhatsApp yang diberikan intervensi video pembelajaran. Hasil lain menunjukan pembelajaran daring dengan menggunakan media group WhatsApp dengan intervensi video pembelajaran lebih baik dan efektif digunakan untuk meningkatkan hasil belajar pada siswa kelas VIII SMP N 1 Air Naningan di masa Pandemi Covid-19.
\end{abstract}

Kata Kunci : Pembelajaran daring, Group WhatsApp, Video Pembelajaran, Hasil belajar siswa.

This is an open access article distributed under the terms of the Creative Commons Attribution 4.0 International License

Website: http://ejournal.umpri.ac.id/index.php/e-DuMath

\section{PENDAHULUAN}

Pembelajaran merupakan inti dari proses pendidikan. Kualitas pendidikan menggambarkan kualitas pembelajaran. Menurut Albitar Septian Syarifudin (2020) dalam penelitiannya menyimpulkan bahwa pembelajaran dapat diartikan sebagai internalisasi ilmu pengetahuan yang terjadi didalam kelas yang melibatkan guru dan siswa dibantu dengan media, alat, metode, dan bahan yang telah dirancang berdasarkan standar pendidikan indonesia dan pola pengembangan kurikulum 2013. Namun kenyataan saat ini berbagai negara di belahan dunia, termasuk Indonesia tengah dilanda dengan wabah suatu penyakit yang disebabkan oleh virus bernama corona atau lebih dikenal dengan 
istilah Covid-19 (Corona Virus Diseases-19). Akibat pandemi Covid-19 telah membuat sistem pembelajaran di sekolah dipaksa berubah secara drastis dari pertemuan tatap muka menjadi pembelajaran daring (online), salah satu sekolah yang menerapkan pembelajaran daring adalah SMP N 1 Air Naningan. Oleh karena itu pembelajaran daring pun menjadi solusi utama demi tetap berlangsungnya kegiatan belajar mengajar di Indonesia.

Agung Rachmat dan Iwan Krisnadi (2020) dalam penelitiannya menemukan bahwa Pembelajaran Daring merupakan kepanjangan dari Pembelajaran dalam jaringan (online) dengan pola pembelajarannya melalui bantuan jaringan internet sehingga akan terjadi interaksi kegiatan belajar mengajar antara siswa dan guru. Pembelajaran daring ini juga dilakukan memanfaatkan teknologi informasi. Menurut Sobron Adi Nugraha, dkk (2020) dalam penelitiannya menyimpulkan bahwa terdapat pengaruh penggunaan media daring learning terhadap hasil belajar matematika siswa kelas IV. Selain itu Jang Mas Subur dan Nadia Rista (2020) dalam penelitiannya menyimpulkan bahwa pengaruh pembelajaran online selama masa darurat Covid-19 terhadap hasil belajar siswa pada mata pelajaran IPS berpengaruh terhadap hasil belajar siswa. Oleh karena itu berdasarkan penelitian-penelitian tersebut penulis berasumsi pembelajaran daring dapat digunakan sebagai solusi pembelajaran pada masa Pandemi Covid-19 karena dapat dilakukan dimanapun dan kapanpun sesuai dengan kebutuhan pengguna.

Berdasarkan wawancarayang penulis lakukan dengan salahsatu guru matematika di SMP N 1 Air Naningan, terkadang muncul berbagai masalah yang dihadapi oleh siswa dan guru di SMP N 1 Air Naningan, salah satu masalah terberat dalam pembelajaran matematika yaitu pada materi pokok persamaan garis lurus. Problematika saat ini adalah masih banyak peserta didik yang menganggap matematika pelajaran yang sulit sehingga berdampak pada hasil belajar siswa yang rendah. Hal tersebut terlihat pada data hasil ulangan harian pada materi pokok persamaan garis lurus saat pembelajaran daring berlangsung di kelas VIII SMP N 1 Air Naningan tahun pelajaran 2020/2021 terdapat rata- rata presentase ketuntasan siswa yaitu 39,1675\% dan 60,8325\% dikategorikan belum tuntas sehingga masih banyak siswa yang belum mencapai Kriteria Ketuntasan Minimum (KKM) yang ditetapkan yaitu 60. Secara umum rata-rata nilai ulangan harian siswa rendah saat pembelajaran daring berlangsung. Menurut Slameto dalam Sri Hayati (2017) salahsatu faktor internal yang mempengaruhi hasil belajar siswa adalah minat dan motivasi. Oleh karena itu kesulitan yang ada dalam mata pelajaran matematika menyebabkan minat dan motivasi untuk belajar matematika masih rendah pada masa pandemi Covid 19 ini.

Motivasi yang rendah diduga disebabkan karena teknik pembelajaran yang berubah secara drastis dengan menggunakan ICT sehingga banyak guru yang belum menguasai teknik pembelajaran tersebut, kemudian keterbatasan dalam hal alat untuk mendukung pembelajaran daring baik pendidik maupun peserta didik, dan durasi pembelajaran online yang relatif lama sehingga siswa merasa cepat bosan karena harus menatap layar gadget berjam-jam, Akibatnya berdampak pada masalah rendahnya hasil belajar siswa.

Untuk mengatasi masalah tersebut maka perlu kreativitas guru mata pelajaran matematika untuk mengembangkan pembelajarannya, baik dalam hal 
metode maupun media yang digunakan untuk meningkatkan hasil belajar siswa. Berbagai media pembelajaran daring pun dicoba dan digunakan pada masa pandemi Covid 19, salah satu media pembelajaran daring yang familiar dan sering digunakan di SMP N 1 Air Naningan yakni media Whatsapp.

Munawaroh, I (2019) dalam penelitiannya mengemukakan cara penggunaan media social WhatsApp ini adalah peserta didik dapat berdiskusi dengan guru misalnya dengan mengirimkan hasil penyelesaian soal-soal latihan sesuai materi apabila ingin mengetahui benar atau salah dari hasil penyelesaian soal tersebut. Peserta didik dapat juga menanyakan permasalahan yang berkaitan dengan soal-soal latihan tersebut. Permasalahan yang ingin ditanyakan dapat dikirimkan di whatsapp group dengan terlebih dahulu mengambil gambar atau foto hasil penyelesaian soal latihan. Gambar atau foto yang dikirimkan dapat dilihat oleh seluruh anggota grup melalui smarthphone. Sehingga peserta didik yang lain dapat mencoba menyelesaikan atau menjawab permasalahan tersebut sebelum diselesaikan atau dijawab oleh guru. Namun karena minimnya interaksi, terlihat hanya beberapa siswa saja yang aktif dalam pembelajaran tersebut dan hanya sedikit siswa yang bertanya mengenai materi yang belum dipahami.

Menurut Nurul Astuty Yensy (2020) dalam Penelitiannya yang bertujuan untuk melihat efektifitas pembelajaran Statistika Matematika dengan menggunakan media WA Group ditinjau dari hasil belajar mahasiswa menyimpulkan bahwa Hasil belajar mahasiswa setelah perkuliahan dengan menggunakan WA Group lebih tinggi dibandingkan dengan hasil belajar mahasiswa sebelum perkuliahan dengan menggunakan WA Group. Senada dengan Eka Indaryani dan Dwi Suliworo (2018) dalam Penelitiannya menyimpulkan bahwa adanya peningkatan dampak pemanfaatan whatsapp dalam meningkatkanmotivasi belajar siswa pada pelajaran fisika. kemudian Eva Margaretha Saragih dan Rahma Yunita Ansi (2020) dalam penelitiannya juga Menyimpulkan bahwaterdapat efektivitas pembelajaran dengan WhatsApp Group pada masa pandemi Covid-19. Sejalan dari beberapa hasil penelitian tersebut, sehingga group WhatsApp dapat menjadi solusi alternatif media pembelajaran daring di masa pandemi Covid-19. Namun dalam penelitian ini peneliti menambahkan intervensi video pembelajaran agar pembelajaran lebih menarik danmenambah pengetahuan dan pemahaman siswa pada materi yang diajarkan. Hal ini sejalan dengan hasil penelitian Agustiningsih (2015)yang menyimpulkan bahwa ada pengaruh penerapan video terhadap hasil belajar siswa sehingga video dapat dijadikan sebagai alternatif media pembelajaran dalam rangka mendukung keberhasilan penerapan kurikulum 2013.

Berdasarkan permasalahan di atas, maka dilakukan penelitian untuk menguji Pembelajaran Daring Menggunakan Media Group Whatsapp dengan Intervensi Video Pembelajaran pada Masa Pandemi Covid 19 pada siswa kelas VIII SMP N 1 Air Naningan.

\section{METODE}


Penelitian ini tergolong penelitian kuantitatif dengan Metode preeksperimental dan design nya adalah one group pretest-postest design. Penelitian ini dilaksanakan dikelas VIII SMP N 1 Air Naningan tahun ajaran 2020-2021. Populasi dari penelitian ini adalah kelas VIII.C, VII.D, VIII.E, dan VIII.F dengan teknik pengambilan sampel yang digunakan yaitu purposive samplingsehingga terpilih 1 sampel yaitu kelas ekperimen yang berjumlah 30 siswa. Instrumen penelitian yang digunakan dalam penelitian ini adalah intervensi video yang diberikan saat pembelajaran menggunakan group WhatsApp berlangsung dan test soal materi pokok persamaan garis lurus yang berjumlah 5 soal. Analisis data dalam penelitian ini dibagi menjadi dua yaitu analisis deskriptif dan inferensial, analisis deskriptif digunakan untuk mencari rata-rata, median, modus, serta serta standar deviasi. Selanjutnya dilakukan statistika inferensial yang meliputi uji asumsi klasik yaitu uji normalitas, uji homogenitas, jika sebaran data normal maka dilanjutkan uji hipotesis yaitu uji paired sample t-test dan jika tidak normal dilanjutkan uji Wilcoxon.

\section{HASIL DAN PEMBAHASAN}

Hasil penelitian ini di fokuskan pada dua aspek yaitu pembelajaran daring dengan menggunakan Group WhatsAppsebelum menggunakan intervensi video dan sesudah menggunakan intervensi video pembelajaran. Pembelajaran daring dilaksanakan dikelas VIII SMP N 1 Air Naningan pada materi persamaan garis lurus dilakukan dengan cara memberikan tes soal uraian sebanyak 5 soal sebelum dilakukan intervensi video pembelajaran (pre test) yang di bagikan melalui group WhatsApp. Dapat data hasil pembelajaran menggunakan Group WhatsApp sebelum intervensi video pembelajaran dilihat pada Tabel 1 berikut ini.

Tabel 1 Deskipsi data Hasil pembelajaran daring

\begin{tabular}{lr}
\hline & Hasil belajar_sebelum \\
Valid N & 30 \\
Minimum & 10 \\
Maximum & 67 \\
Mean & 37,6 \\
Std.Deviation & 14,35895 \\
\hline
\end{tabular}

Nilai yang diperoleh yaitu hasil dari lima jawaban soal test uraian yang masing-masing nomor soal mempunyai point yang berbeda-beda. Nilai yang di dapat dari pretest sebelum intervensi video yaitu nilai terendah 10 dan nilai tertinggi 67 dengan rata-rata nilai yang diperoleh adalah 37,6 dan standar deviasi 14,35895. hal ini menunjukan bahwa hasil pembelajaran daring menggunakan Group WhatsApp sebelum intervensi video pembelajaran perlu perhatian lebih agar hasil belajar meningkat dengan pemberian intervensi video pembelajaran dalam pembelajaran daring menggunakan group WhatsApp yang dilaksanakan pada masa pandemi Covid-19 saat ini.

Pembelajaran daring dengan menggunakan Group WhatsApp sesudah intervensi video kelas VIII SMP N 1 Air Naningan tentang materi persamaan garis lurus dilakukan dengan cara memberikan tes soal uraian sebanyak 5 soal 
sesudah dilakukan intervensi video pembelajaran (post test) yang di bagikan melalui group WhatsApp. Dapat dilihat pada Tabel 2 berikut ini.

Tabel 2 Deskipsi data Hasil pembelajaran daring

\begin{tabular}{lr} 
& Hasil belajar_sesudah \\
Valid N & 30 \\
Minimum & 50 \\
Maximum & 85 \\
Mean & 68,37 \\
Std.Deviation & 9,349473 \\
\hline
\end{tabular}

Pengetahuan siswa kelas VIII tentang materi persamaan garis lurus sesudah intervensi video pembelajaran yang dibagikan melalui group WhatsApp yaitu hasil nilai didapat dari posttest setelah intervensi seluruh video pembelajaran diperoleh nilai minimal 50 dan nilai maksimal 85 serta rata-rata nilai diperoleh 68,37 dan standar deviasi 9,349473. Berdasarkan data tersebut rata-rata hasil pembelajaran daring menggunakan Group WhatsApp sesudah intervensi video pembelajaran berhasil dan mampu meningkatkan hasil belajar siswa. Perbandingan hasil pembelajaran daring dengan menggunakan group WhatsApp sebelum dan sesudah diterapkan intervensi video pembelajaran, dapat dilihat dalam Gambar 1 diagram batang berikut ini.



\section{Gambar 1 Perbandingan rata-rata}

Berdasarkan diagram tersebut maka rata-rata hasil belajar antara pembelajaran daring dengan menggunakan group WhatsApp dengan pembelajaran daring dengan menggunakan group WhatsAppyang diberikan intervensi video pembelajaran terjadi peningkatan, namun perlu dilakukan uji analisis untuk menentukan apakah hipotesisnya diterima ataupun ditolak. langkah pertama yaitu uji normalitas untuk mendapatkan data apakah data 
berdistribusi normal atau tidak sehingga didapatkan data pada Tabel 3 berikut ini.

Tabel 3 hasil uji normalitas

\begin{tabular}{lc}
\multicolumn{1}{c}{ Uji Normalitas } & Nilai $\boldsymbol{L}_{\boldsymbol{O}}$ \\
Hasilbelajar sebelum & 0,116665 \\
Hasil belajar sesudah & 0,152053 \\
\hline
\end{tabular}

Uji normalitas menunjukan bahwa nilai $\mathrm{p}$ sebelum intervensi video $L_{O}=$ $0,116665<L_{t}(0,05 ; 30)=0,187$ maka data berdistribusi normal, dan nilai

$\mathrm{p}$ sesudah intervensi video $L_{O}=0,152053<L_{t}(0,05 ; 30)=0,187$ maka data berdistribusi normal. Keduanya mempunyai distribusi data normal dan bisa melakukan uji beda dua rata-rata berpasangan. Hasil nilai atau skor yang diperoleh oleh siswa sebelum intervensi video adalah 37,6 dan hasil nilai atau skor yang diperoleh responden sesudah intervensi video adalah 68,37 . hasil Uji$\mathrm{t}$ berpasangan dapat dilihat pada Tabel 4 berikut ini :

Tabel 4 hasil Uji-t berpasangan (Paired Samples Test)

\begin{tabular}{lc}
\hline Uji-t berpasangan & $\mathbf{1 1 , 6 7 3 5}$ \\
(Paired Samples Test) & Ha diterima \\
\hline
\end{tabular}

Uji-t berpasangan dilakukan pada kedua kelompok dengan hasil $\left|t_{\text {hit }}\right|>$ $t_{0,05 ; 29}$ yaitu 11,6735 $>2,04523$ artinya $\mathrm{Ha}$ diterima. Sehingga dapat disimpulkan bahwa terdapat perbedaan rata-rata hasil belajar antara pembelajaran daring dengan menggunakan media group whatsapp dengan pembelajaran daring dengan menggunakan media group whatsapp yang diberikan intervensi video pembelajaran. Uji-t berpasangan pada SPSS dilakukan pada kedua kelompok dengan hasil probabilitas tabel output "Paired Samples Test" diketahui nilai Sig. (2-tailed) adalah sebesar 0,000<0,005, maka Ho ditolak dan Ha diterima. sehingga dapat disimpulkan bahwa terdapat perbedaan rata-rata hasil belajar antara pembelajaran daring dengan menggunakan media group whatsapp dengan pembelajaran daring dengan menggunakan media group whatsapp yang diberikan intervensi video pembelajaran.

Berdasarkan hasil analisis data, diperoleh $t_{\text {hitung }}=11,6735$ dan dengan $\alpha=5 \%$ didapatkan $t_{\text {tabel }}=t_{0,05 ; 29}=2,04523$ karena $11,6735>2,04523$ berarti $t_{\text {hitung }}>t_{\text {tabel }}$ maka dapat disimpulkan bahwa $\mathrm{H}_{0}$ (tidak terdapat perbedaan rata-rata hasil belajar antara pembelajaran daring dengan menggunakan media group whatsapp dengan pembelajaran daring dengan menggunakan media group whatsapp yang diberikan intervensi video pembelajaran) ditolak dan $\mathrm{H}_{\mathrm{a}}$ (terdapat perbedaan rata-rata hasil belajar antara pembelajaran daring dengan menggunakan media group whatsapp dengan pembelajaran daring dengan menggunakan media group whatsapp yang diberikan intervensi video 
pembelajaran) diterima. karena terdapat perbedaan rata-rata hasil belajar antara pembelajaran daring dengan menggunakan media group whatsapp dengan pembelajaran daring dengan menggunakan media group whatsapp yang diberikan intervensi video pembelajaran, sehingga diperoleh Hasil nilai atau skor yang diperoleh oleh siswa sebelum intervensi video adalah 37,6 dan hasil nilai atau skor yang diperoleh siswa sesudah intervensi video adalah 68,37 , berarti pembelajaran daring dengan menggunakan media group WhatsApp dengan intervensi video pembelajaran lebih baik dan efektif digunakan untuk meningkatkan hasil belajar pada siswa kelas VIII SMP N 1 Air Naningan di masa Pandemi Covid-19 ini.

Hal ini didukung oleh penelitian-penelitian sebelumnya yaitu menurut Eva Margaretha Saragih dan Rahma Yunita Ansi (2020) dalam penelitiannya menyimpulkan bahwa terdapat efektivitas pembelajaran dengan WhatsApp group pada masa Pandemi Covid-19. Kemudian menurut Nurul Astuty Yensy (2020) dalam penelitiannya menyimpulkan bahwa hasil belajar mahasiswa setelah perkuliahan dengan menggunakan WhatsApp group lebih tinggi dibandingkan dengan hasil belajar mahasiswa sebelum perkuliahan dengan menggunakan WhatsApp group. Sementara itu Eka Indriyani dan Dwi Suliworo (2018) dalam penelitiannya menyimpulkan bahwa terdapat peningkatan hasil belajar siswa yang signifikan sebelum dan sesudah menggunakan WhatsApp pada pembelajaran fisika. hanya saja terdapat perbedaan penelitian yang penulis lakukan dengan penelitian-penelitian sebelumnya, perbedaan tersebut terletak pada penggunaan intervensi video pembelajaran sebagai variasi pembelajaran daring pada media group WhatsApp dimasa Pandemi Covid-19 di kelas VIII SMP N 1 Air Naningan.

\section{SIMPULAN}

Berdasarkan pengolahan dan analisis data disimpulkan bahwa terdapat perbedaan rata-rata hasil belajar siswa antara pembelajaran daring menggunakan media group WhatsApp dengan pembelajaran daring menggunakan media group WhatsApp yang diberikan intervensi video pembelajaran. Hasil lain menunjukan pembelajaran daring dengan menggunakan media group WhatsApp dengan intervensi video pembelajaran lebih baik dan efektif digunakan untuk meningkatkan hasil belajar pada siswa kelas VIII SMP N 1 Air Naningan di masa Pandemi Covid 19 serta dapat menjadi alternatif dalam pembelajaran daring di masa pandemi Covid-19 ini.

\section{DAFTAR PUSTAKA}

Agung Rachmat dan Iwan Krisnadi. (2020). "Analisis Efektifitas Pembelajaran Daring (Online) Untuk Siswa SMK Negeri 8 Kota Tangerang Pada Saat Pandemi Covid 19". Universitas Mercu Buana, Menteng, Jakarta, Indonesia.

Agustiningsih. (2015). "Video" Sebagai Alternatif Media Pembelajaran Dalam Rangka Mendukung Keberhasilan Penerapan Kurikulum 2013 Di Sekolah Dasar.Pancaran.4(1).55-68. 
Eka Indaryani dan Dwi Suliworo. (2018).Dampak pemanfaatan WhatsApp dalam Meningkatkan Motivasi Belajar Siswa pada Pembelajaran Fisika.Prosiding Seminar Nasional Quantum.25-31

Eva Margaretha Saragih dan Rahma Yunita Ansi. (2020). Efektivitas Penggunaan WhatsApp Group Selama Pandemi Covid-19 Bagi Pelaku Pendidik.Prosiding Seminar Nasional Multidisiplin Ilmu Universitas Asahan ke-4 tahun 2020 "Sinergi Hasil penelitian dalam Menghasilkan Inovasi di Era Revolusi 4.0”. 207-212. https://www.whatsapp.com/about/?lang=id ).

Jang Mas Subur \& Nadia Rista.(2020)."Pengaruh Pembelajaran Online pada Masa Pandemi Covid-10 terhadap Hasil Belajar Mata Pelajaran Ilmu Pengetahuan Sosial Siswa Kelas VIII di SMP Walisongo Bekasi. Jurnal Sosial dan Ilmu Ekonomi.5(2).156-161.

Menteri Pendidikan. (2020). Surat Edaran Nomor 3 Tahun 2020 Tentang Pelaksanaan Pendidikan dalam Masa Darurat CoronaVirus (COVID-19).

Munawaroh, I. (2019). Penggunaan Media Sosial Sebagai Upaya Meningkatkan Hasil Belajar Matematika Peserta Didik Kelas 9 di SMP N 1 Sindangkasih Kabupaten Ciamis Tahun Pelajaran 2017/2018. Prosiding Seminar Nasional \& Call For Papers. Volume 1 No. 9. ISBN: 978-602-9250-39-8. Tasikmalaya: Program Studi Magister Pendidikan Matematika, Universitas Siliwangi.

Nurul Astuty Yensy. (2020)." Efektifitas Pembelajaran Statistika Matematika melalui Media Whatsapp Group Ditinjau dari Hasil Belajar Mahasiswa (Masa Pandemik Covid 19)". Jurnal Pendidikan Matematika Raflesia.05(02).65-74.

Subron Adi Nugraha, Dkk. (2020).Studi Pengaruh Daring Learning terhadap Hasil Belajar Matematika Kelas IV.Jurnal Inovasi Penelitian.1(3).265-276.

Syarifudin, Albitar Septian. (2020). "Implementasi Pembelajaran Daring Untuk Meningkatkan Mutu Pendidikan sebagai Dampak diterapkannya Social Distancing”. Jurnal Pendidikan Bahasa dan Sastra Indonesia.5(1).31-34. 